\title{
PELATIHAN PENGGUNAAN GOOGLE DRIVE SEBAGAI MEDIA PENYIMPANAN DAN BERBAGI BAHAN AJAR BAGI GURU SMP NEGERI 3 KALIMANAH
}

\author{
Ali Nur Ikhsan'1), Jali Suhaman'1), Muslimin Hidayat ${ }^{1)}$ \\ 1)Program Studi Informatika, Fakultas IImu Komputer, Universitas Amikom Purwokerto, Purwokerto, Jawa Tengah, Indonesia \\ Corresponding author : Ali Nur Ikhsan \\ E-mail : alinurikhsan@amikompurwokerto.ac.id
}

Diterima 12 September 2020, Direvisi 16 September 2020, Disetujui 17 September 2020

\begin{abstract}
ABSTRAK
Proses pembelajaran di masa pandemik virus Covid-19 mendorong semua pihak menggunakan media online sebagai alternatif dalam melaksanakan kegiatan pembelajaran secara tatap muka. Para Guru di SMP Negeri 3 Kalimanah terbebani dengan besarnya file penyimpanan data karena harus mengirim data satu-persatu ke siswa didiknya melalui Whatsapp sehingga media penyimpanan Smartphone penuh. Dengan adanya permasalahan tersebut tim pengabdian kepada masyarakat $(\mathrm{PkM})$ berinisiatif untuk melakukan pelatihan penggunaan Google Drive sebagai media penyimpanan dan berbagi bahan ajar bagi guru SMP Negeri 3 Kalimanah untuk memperkenalkan media penyimpanan berbasis cloud yang dapat diakses kapan saja dan dimana saja. Metode yang digunakan dalam pelatihan ini yaitu berupa workshop. Tim PkM melakukan pelatihan secara langsung dengan 1 narasumber sebagai pemateri workshop dan 2 pendamping untuk mendampingi guru dalam pelaksanaan workshop. Pelatihan ini dapat menambah pengetahuan guru dalam memanfaatkan Google Drive sebagai media penyimpanan dan berbagi bahan ajar yang dapat digunakan dalam proses pembelajaran di masa pandemik virus Covid-19.
\end{abstract}

Kata kunci: google drive; media penyimpanan; cloud ; workshop.

\begin{abstract}
The learning process during the Covid-19 virus pandemic encouraged all parties to use online media as an alternative in carrying out face-to-face learning activities. Teachers at SMP Negeri 3 Kalimanah are burdened by the size of the data storage files because they have to send data one by one to their students via Whatsapp so that the Smartphone storage media is full. With these problems, the community service team $(\mathrm{PkM})$ took the initiative to conduct training on using Google Drive as a storage medium and sharing teaching materials for teachers of SMP Negeri 3 Kalimanah to introduce cloudbased storage media that can be accessed anytime and anywhere. The method used in this training is a workshop. The PkM team conducted direct training with 1 resource person as a workshop speaker and 2 assistants to assist teachers in the implementation of the workshop. This training can increase teacher knowledge in utilizing Google Drive as a storage medium and sharing teaching materials that can be used in the learning process during the Covid-19 virus pandemic.
\end{abstract}

Keywords: google drive; storage media; cloud; workshop.

\section{PENDAHULUAN}

SMPN 3 Kalimanah merupakan SMP dengan fasilitas yang lengkap, salah satu fasilitas yang ada yaitu adanya akses internet yang dimanfaatkan guru dalam menyiapkan materi ajar. Dalam pemakaian fasilitas internet sebagian besar guru belum memanfaatkan untuk menyimpan dan berbagi bahan ajar secara cloud. Guru-guru lebih sering menyimpan bahan ajar di flashdisk dan di dalam masing-masing personal computer (PC). Hal ini menjadikan beberapa resiko data rusak, atau bahkan hilang karena tidak ada back-up. Selain itu pada saat guru berhalangan hadir dan digantikan guru pengganti harus meminta data yang membutuhkan akses membuka PC kantor atau bisa jadi bahan ajar ada di flashdisk guru yang berhalangan hadir sehingga untuk dapat memperoleh data membutuhkan waktu yang lama.

Berdasarkan permasalahan yang ada pada mitra, tim pengabdian kepada masyarakat (PkM) berupaya untuk melakukan pelatihan pemanfaatan Google Drive sebagai media penyimpanan data \& berbagi bahan ajar. Metode yang digunakan yaitu dengan melakukan workshop/pelatihan dan pendampingan penggunaan Google Drive 
untuk media penyimpanan dan berbagi bahan ajar. Tim PkM melakukan pelatihan atau workshop pemanfaatan fasilitas berbagi online menggunakan Google Drive agar data pemakaian bersama bisa digunakan dengan maksimal dan bisa dikerjakan secara bersamaan(Astuti et al., 2020).

Penggunaan Google Drive belum banyak dimanfaatkan oleh guru SMPN 3 Kalimanah untuk media penyimpanan dan berbagi data/informasi. Google Drive mudah digunakan karena dalam penggunaannya dapat menggunakan akun Google. Google drive merupakan suatu media penyimpanan data online (daring) berbasis cloud atau Internet yang dikembangkan dan diperkenalkan oleh Google pada tanggal 24 April 2012 (Ainun, 2019). Pada dasarnya layanan Google Drive sama seperticloud storage lain semacam dropbox atau OneDrive. Aplikasi ini tersedia dalam bentuk dekstop ataupun smartphone. Pada beberapa jenis ponsel Google Drive atau GDrive menjadi aplikasi bawaan yang terinstal secara otomatis di sistem (Syukri, 2020). Dengan menggunakan Google Drive yang berbasis cloud storage terdapat banyak keuntungan dibandingkan dengan penyimpanan data secara offline, selain itu data yang tersimpan di dalam cloud storage akan dapat diakses dimana dan kapan saja. Cloud storage akan diintegrasikan ke berbagai perangkat untuk mendapatkan kemudahan pengaksesan seperti ke perangkat mobile (smartphone), tablet serta personal computer (Santiko \& Rosidi, 2018).

Berikut beberapa fasilitas Google Drive yang dapat digunakan oleh penggunanya untuk membuat, menyimpan dan membagi dokumen dengan pengguna lainnya. Secara umum Google Drive memiliki fitur sebagai berikut (Oktaviandi et al., 2015):

1. Kapasitas penyimpanan gratis sebesar 5 GB

2. Fasilitas untuk membuat dokumen

3. Berbagi (sharing) dokumen

4. Terintegrasi dengan layanan Google lainnya

5. Fasilitas Pencarian

6. Kemampuan menampilkan berbagai tipe file

7. Kemampuan menjalankan aplikasi Dengan menggunakan Google Drive dapat menghemat keterbatasan alat penyimpanan data seperti flashdisk, hardisk dan lain-lain. Pemanfaatan google drive dapat membantu guru menciptakan suasana belajar yang nyaman dan menyenangkan. Guru dapat meng-upload materi ajar berupa video, lagu ataupun kuis online yang interaktif. Dengan begitu, para peserta didik dapat mengakses, mengerjakan tugas dan berdiskusi langsung dengan peserta didik lainnya sehingga tercipta suasana belajar yang berbeda, menarik dan nyaman(Ismawan et al., 2018).

\section{METODE}

Metode pelaksanaan pelatihan Google Drive ini dilakukan dengan cara workshop. Workshop merupakan salah satu kegiatan dari pertemuan dimana sekelompok orang yang memiliki minat, keahlian, dan profesi di bidang tertentu terlibat dalam diskusi dan kegiatan intensif pada subjek atau proyek tertentu (Ekonomi, 2020).

Pembahasan dalam kelas workshop biasanya bersifat ilmiah dan namun ada bagian dari sesi workshop yang diisi dengan praktik (Sari, 2019). Tim Pengabdian kepada Masyarakat (PkM) melakukan pembagian tugas dengan Ketua pelaksana sebagai narasumber yang memandu berjalannya workshop dan Anggota pelaksana bertugas sebagai pendamping yang mengarahkan para guru mengikuti workshop.

Fase proses belajar dalam program workshop yang dimaksud meliputi tahap perencanaan, pelaksanaan, dan evaluasi (Septyara Dwi Anggraeni, 2017). Tahapan yang dilakukan oleh tim PkM dalam kegiatan pelatihan penggunaan google Drive sebagai media penyimpanan dan berbagi bahan ajar sebagai berikut:

1. Tahap Persiapan

Pada tahap ini tim PkM melakukan survey tempat dan koordinasi dengan pihak SMP Negeri 3 Kalimanah untuk melakukan pelatihan Google Drive. Kemudian penyusunan materi dan perlengkapan yang diperlukan dalam kegiatan workshop.

2. Tahap Pelaksanaan

Pada tahap ini dilakukan dilakukan dengan penyampaian materi dengan diikuti dengan workshop penggunaan Google Drive sebagai media penyimpanan dan berbagi bahan ajar. Para guru diberi kesempatan untuk melakukan diskusi dengan cara tanya jawab dan melakukan praktik secara langsung untuk menggunakan Google Drive ke mata pelajaran yang diampu.

3. Tahap Evaluasi

Pada tahap ini tim PkM melakukan evaluasi kegiatan yang telah dilakukan meliputi persiapan, jalannya kegiatan workshop, kendala dan hasil dari kegiatan pelatihan penggunaan Google Drive untuk media penyimpanan dan berbagi bahan ajar. 
Metode workshop dipilih karena lebih tepat digunakan untuk kegiatan yang bersifat praktikum atau membutuhkan penanganan secara langsung agar peserta dapat dengan mudah mengikuti dan memahami tentang kegiatan yang diikuti. Keaktifan peserta dalam menanggapi materi yang diberikan adalah kunci sukses dari sebuah workshop (Putra, 2020).

\section{HASIL DAN PEMBAHASAN}

Kegiatan pelatihan penggunaan Google Drive sebagai media penyimpanan dan berbagi bahan ajar bagi guru SMP Negeri 3 Kalimanah diawali dengan sambutan bapak Sri Widadi, S.Pd selaku plt. Kepala SMP Negeri 3 Kalimanah yang mengharapkan kegiatan tersebut bisa diikuti dengan baik dan lancar. Sambutan plt. Kepala SMP Negeri 3 Kalimanah dapat dilihat pada Gambar 1.

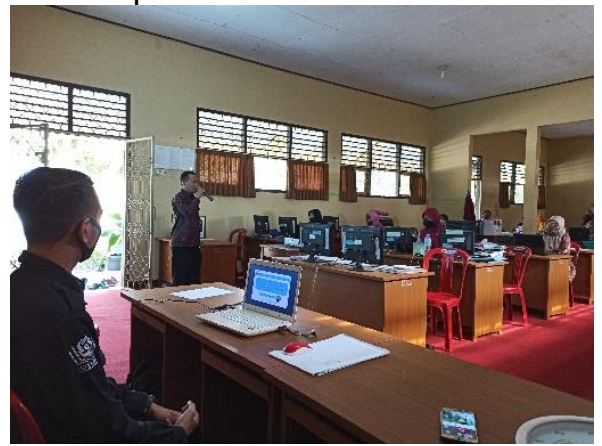

Gambar 1. Sambutan Kepala SMP Negeri 3 Kalimanah

Selanjutnya kegiatan pelatihan sepenuhnya diserahkan kepada tim PkM dengan cara dipandu dari pengenalan Google Drive, fungsi dan kegunaan serta pemanfaatan Google Drive sebagai media penyimpanan dan berbagi bahan ajar. Kegiatan ini dilakukan secara bertahap dengan menyesuaikan kemampuan para guru dalam mengikuti langkah-langkah dalam menggunakan Google Drive. Kegiatan pelatihan Google Drive dapat dilihat pada Gambar 2.

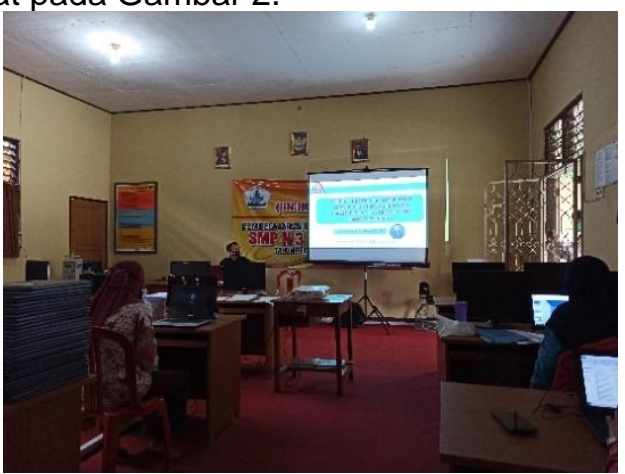

Gambar 2. Kegiatan Pelatihan Google Drive
Para guru sangat antusias dengan adanya pelatihan Google Drive ini seperti yang ditampilkan pada Gambar 3. Mereka berharap agar pelatihan-pelatihan sering dilakukan di sekolah ini agar para guru dapat menambah pengetahuan baru yang nantinya dapat bermanfaat dalam pelaksaan kegiatan belajar mengajar maupun digunakan untuk kepentingan pribadinya.

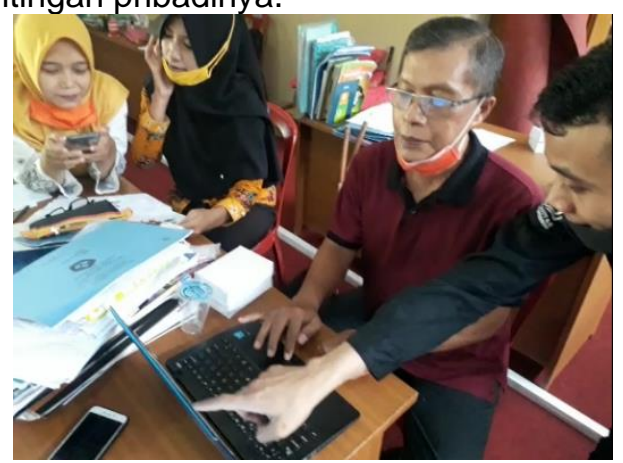

Gambar 3. Antusias guru dalam pelatihan Google Drive

Kegiatan pelatihan Google Drive ini berjalan dengan lancar dan sebagian besar guru dapat mengikuti dengan baik dan paham dengan penggunaan Google Drive sebagai media penyimpanan dan berbagi bahan ajar secara cloud. Acara pelatihan ditutup dengan foto bersama tim PkM dan para Guru seperti pada Gambar 4.

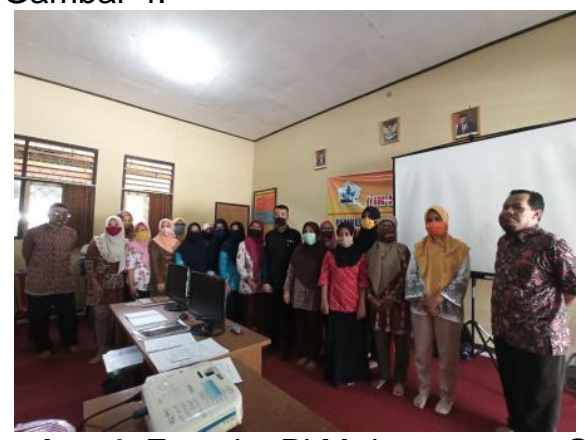

Gambar 4. Foto tim PkM dengan para Guru SMP Negeri 3 Kalimanah

\section{SIMPULAN DAN SARAN}

Kegiatan pelatihan pemanfaatan Google Drive sebagai media penyimpanan data \& berbagi bahan ajar ini berjalan dengan lancar. Hal ini dibuktikan dengan banyaknya guru yang mengikuti pelatihan dan langsung mempraktikan dalam kegiatan belajar mengajar. Pemanfaatan Google Drive ini sangat disarankan untuk menyimpan data-data yang diperlukan dalam keadaan mendesak, sehingga dalam mengakses data yang diperlukan dapat diperoleh dengan mudah dan cepat karena tersimpan di cloud yang tersambung dengan internet. 


\section{UCAPAN TERIMAKASIH}

Penulis menghaturkan ucapan terima kasih kepada Universitas Amikom Purwokerto dan LPPM Universitas Amikom Purwokerto, yang menjadi sponsor sehingga kegiatan pengabdian kepada masyarakat ini dapat terealisasi.

\section{DAFTAR RUJUKAN}

Ainun. (2019). PENGERTIAN GOOGLE DRIVE: Fungsi, Manfaat \& Cara Menggunakan.

https://salamadian.com/pengertiangoogle-drive/

Astuti, Y., Kusumarini, N., \& Farida, L. D. (2020). PENINGKATAN KINERJA GURU DALAM PENGELOLAAN ADMINISTRASI SEKOLAH MENGGUNAKAN FASILITAS BERBAGI ONLINE. Jurnal Penelitian Dan Pengabdian Kepada Masyarakat UNSIQ, 7(2), 128-133.

Ekonomi, G. (2020). Sarjana Ekonomi - Tempat Belajar IImu Ekonomi Secara Gratis. https://sarjanaekonomi.co.id/workshop/

Ismawan, F., Irfansyah, P., \& Apriyani, D. D. (2018). Pengoptimalan Cloud Storage Google Drive sebagai Media Pembelajaran untuk Guru SMP dan SMA. Jurnal PkM Pengabdian Kepada Masyarakat, $1(01), \quad 61$. https://doi.org/10.30998/jurnalpkm.v1i01. 2362

Oktaviandi, R., Dahliyusmanto, \& Anhar. (2015). Pemanfaatan layanan google drive untuk menjalankan aplikasi pengontrolan peralatan listrik menggunakan usb comm port. 2(2), 1-13.

Putra. (2020). PENGERTIAN SEMINAR, Workshop, Konferensi, Simposium, Lokakarya \& Contoh. https://salamadian.com/pengertianseminar-workshop/

Santiko, I., \& Rosidi, R. (2018). Pemanfaatan Private Cloud Storage Sebagai Media Penyimpanan Data E-Learning Pada Lembaga Pendidikan. Jurnal Teknik Informatika, 10(2), 137-146. https://doi.org/10.15408/jti.v10i2.6992

Sari, F. (2019). Memahami Perbedaan Workshop, Training dan Seminar. https://www.gamelab.id/news/115memahami-perbedaan-workshoptraining-dan-seminar

Septyara Dwi Anggraeni, S. (2017). Pelaksanaan Program Workshop "Belajar Efektif” Untuk Orang Tua. JIV-Jurnal Ilmiah Visi, 12(2), 129-136. https://doi.org/10.21009/jiv.1202.5

Syukri, M. Y. (2020). Pengantar Google Drive. https://prezi.com/p/8nzk-

\section{b_2rkbh/pengantar-google-drive/}

